Nigerian Journal of Physiological Sciences 22 (1-2): 65-68 @Physiological Society of Nigeria, 2007

Available online/abstracted at http://www.biolineinternational.org.br/njps; www.ajol.info/journals.njps; www.cas.org

\title{
SERUM PROTEIN AND ENZYME LEVELS IN RATS FOLLOWING ADMINISTRATION OF ANTIOXIDANT VITAMINS DURING CAFFEINATED AND NON-CAFFEINATED PARACETAMOL INDUCED HEPATOTOXICITY
}

\author{
V.S. EKAM* and P. E. EBONG \\ Department of Biochemistry, College of Medical Sciences, University of Calabar, Calabar, Nigeria \\ E-mail: ekvisa@yahoo.com Tel: +2348053300565.
}

\begin{abstract}
Summary: The effects of caffeinated and non-caffeinated paracetamol administration, with or without vitamins $\mathrm{A}$ and $\mathrm{E}$ supplementation on the protein and enzyme levels in Wistar albino rats were investigated using cafeinated paracetamol and paracetamol as caffeinated and non-caffeinated paracetamol respectively, and water soluble acetic acid derivatives of vitamins A and E. Serum AST, ALT and ALP levels $(\mathrm{u} / \mathrm{l})$ significantly increased $(\mathrm{P}<0.05)$ following paracetamol administration. Caffeination as well as administration of vitamins $A$ and $E$ caused significant decreases $(P<0.05)$ in AST and ALP levels in all test groups when co-administered with paracetamol and in ALT level except in the cafeinated paracetamol + Vitamin E group in which ALT and ALP level except in the cafeinated paracetamol + vitamin E group in which ALT and ALP levels significantly increased $(\mathrm{P}<0.05)$. Total serum protein level $(\mathrm{g} / 100 \mathrm{ml})$ significantly increased following caffeination as well as during coadministration of cafeinated paracetamol and Vitamin E; and significantly decreased during coadministration of paracetamol and vitamin A. Paracetamol administration without caffeination or supplementation with vitamin A and E can therefore cause increases in serum liver enzymes that is suggestive of liver necrosis which can be ameliorated to varying degrees by caffeine, vitamin $\mathrm{A}$ and $\mathrm{E}$.
\end{abstract}

Key Words: Paracetamol, liver enzymes, cafeinated paracetamol, vitamins A and E

\begin{abstract}
Introduction
Paracetamol or acetaminophen is a popular domestic analgesic and antipyretic for adults and children. It is a major metabolite of the now obsolete phenacetin, with an analgesic effect, which is similar to that of aspirin. In therapeutic doses, acetaminophen is usually well tolerated and free from side effects and interactions with other drugs. Its easy availability as well as ease of acquisition to the public even without prescription has led to the increase in reported cases of toxicity caused by paracetamol. The first reports of paracetamol poisoning in humans describing hepatic necrosis provoked a series of animal studies which demonstrated that acute centrilobular hepatic necrosis with collapse of the reticulum framework could be produced in some species, although there were differences in susceptibility in various species (Thomas, 1993).

In adult humans, hepatotoxicity may occur after ingestion of a single dose of 10 to $15 \mathrm{~g}$ (150 to $250 \mathrm{mg} / \mathrm{kg}$ ) of acetaminophen; doses of 20 to $25 \mathrm{~g}$ or more are potentially fatal. Clinical indications of hepatic damage become manifest within 2 to 4 days of ingestion of toxic
\end{abstract}

doses. Plasma aminotransferases are elevated and the concentration of bilirubin in plasma may be increased and prothrombin time is prolonged. About $10 \%$ of poisoned patients who do not receive specific treatment develop severe liver damage; of these, 10 to $20 \%$ eventually die of hepatic failure. Biopsy of the liver reveals centrilobular necrosis with sparing of the periportal area (Hardman et at, 1996).

Co-administration of paracetamol using fixed ratio drug combinations is increasingly gaining popularity. $500 \mathrm{mg}$ paracetamol with $30 \mathrm{mg}$ caffeine preparations are increasingly being introduced into the market in various trade names like cafeinated paracetamol, Medik-55, Boska etc. Tablets containing paracetamol (325mg) plus $32.5 \mathrm{mg}$ of dextropropoxyphene (co-proxamol, Distalgesic) have been used to provide an effective dose of both drugs as well as give a mild euphoriant effect. Despite the benefit of rapid analgesic effect and the probable decrease in toxicity, coadministration with these agents is still a cause of concern (Laurence et al, 1997).

Experimental evidence suggests that stress may contribute to degenerative disorders 
and enhancement of tumor growth (Maier et al, 1994) which is partly associated with reduced immune response as a result of micronutrient depletion. Physiological stress has been reported to decrease plasma levels of vitamins $\mathrm{A}, \mathrm{E}, \mathrm{B}_{6}$ and C (Louw et al, 1991). During the past several years, major epidemiological studies have addressed the role of the antioxidant vitamins $\mathrm{A}, \mathrm{C}$, and $\mathrm{E}$ in the protection against cardiovascular and malignant diseases. A plausible conclusion from this emerging body of literature is that nutrient deficiency increases the risk for disease, and replacement of such deficiencies may be expected to confer benefits (Marcus and Coulston, 1996).

\section{Materials and Methods}

Forty-two albino rats of wistar strain weighing between 200 to $300 \mathrm{~g}$ were obtained from the animal house of the Department of Biochemistry, university of Calabar. They were kept under constant environmental and nutritional conditions throughout the experiment. The animals were allowed free feeding with a standard diet and drinking water ad libitum. They were divided into seven experimental groups, each consisting of six rats and treated as follows:

Group 1:Distilled water

Group 2:Paracetamol

Group 3:Cafeinated paracetamol

Group 4: Paracetamol + vitamin A

Group 5: Paracetamol + vitamin E

Group 6:Cafeinated paracetamol + Vitamin A

Group 7:Cafeinated paracetamol + Vitamin E

Cafeinated paracetamol and paracetamol were administered as caffeinated and noncaffeinated paracetamol, using oral doses of $171.43 \mathrm{mg} / \mathrm{kg}$. Vitamin E acetate (Ephynal) and vitamin $\mathrm{A}$ acetate were administered as vitamins $\mathrm{E}$ and A using oral doses of $4.286 \mathrm{mg} / \mathrm{kg}$ and 1428.57 i.u $/ \mathrm{kg}$ respectively. At the end of the treatment period of 14 days, the animals were sacrificed after overnight fasting. Blood was collected into plane screw cap bottles for serum collection: this was allowed to stand for 2 hours for clotting to take place. The serum was removed using a Pasteur pipette into another set of tubes, after spinning in a MSE clinical centrifuge at $1000 \mathrm{rpm}$ for 5 minutes. Serum protein was estimated using the Biuret method of Doninger et al., 1972. Alanine amino transferase and Aspartate aminotransferase activities were determined by the method of Mathieu et al., 1982. Alkaline phosphatase activity in serum was estimated by kit method of Tietz, (1982); which is based on the measurement of the rate of hydrolysis of phosphate esters.

Statistical Analysis

Students' t - test and analysis of variance (ANOVA) were used to analyze the data. Values of $\mathrm{P}<0.05$ were regarded as significant.

\section{Results}

The total serum protein and the concentration of some liver enzymes in serum were measured in rats undergoing treatments with caffeinated and non-caffeinated paracetamol alone as well as those supplements with vitamins $\mathrm{A}$ and $\mathrm{E}$ and in control rats. Enzymes assayed were Alanine aminotransferase (ALT), Aspartate aminotransferase (AST) and Alkaline phosphate (ALP). The effect of treatment on these parameters is shown in table1. The total serum protein and the concentrations of enzymes measured were observed to vary significantly $(p<0.05)$ among and within the test groups and the control. From the results obtained, There was a significant increase $(p<0.05)$ in total serum protein of the groups on cafeinated paracetamol $(7.53 \pm 1.07)$ and paracetamol + Vitamin E $(8.58 \pm 0.81)$ as well as a significant decrease in the group on cafeinated paracetamol + Vitamin A $(4.66 \pm 0.43)$ compared to the paracetamol group. The protein content $(\mathrm{g} / 100 \mathrm{ml})$ was however significantly reduced $(\mathrm{p}$ $<0.05)$ in the cafeinated paracetamol + Vitamin A group (4.66 \pm 0.43$)$ compared to the cafeinated paracetamol group $(7.53 \pm 1.07)$ and significantly increased $(\mathrm{p}<0.05)$ in the paracetamol + Vitamin E group $(8.58 \pm 0.81)$ compared to the paracetamol + Vitamin A group $(6.29 \pm 1.05)$ compared to the cafeinated paracetamol + vitamin A group.

The concentration of ALP (U/L) in the paracetamol treated group $(121.90 \pm 10.62)$ was significantly higher $(\mathrm{p}<0.05)$ than that of the control group $(76.01 \pm 2.81)$. The reductions in ALP (U/L) in the groups on cafeinated paracetamol, paracetamol + Vitamin $A$, paracetamol + Vitamin E, cafeinated paracetamol + Vitamin $A$ and cafeinated paracetamol + Vitamin E were significant $(\mathrm{p}<$ 0.05) compared to the paracetamol group. Coadministration of Vitamin A with cafeinated paracetamol (59.93 \pm 4.89) produced a significant reduction $(\mathrm{p}<0.05)$ in ALP $(\mathrm{U} / \mathrm{L})$ compared with the cafeinated paracetamol group. There was however a significant increase $(\mathrm{p}<0.05)$ in ALP (U/L) in the cafeinated paracetamol + Vitamin A group (59.93 \pm 4.89$)$.

There were significant differences $(\mathrm{p}<$ $0.05)$ in ALT and AST (U/L) among and within 
the test groups. Paracetamol administration produced significant increases $(\mathrm{p}<0.05)$ in both AST and ALT (U/L) $(28.28 \pm 1.96$ and $114.34 \pm$ $0.55)$ compared to the control group (17.51 \pm 1.42 and $73.81 \pm 1.45)$. There were significant decreases $(\mathrm{p}<0.05)$ in AST and ALT in the cafeinated paracetamol paracetamol + Vitamin A. cafeinated paracetamol + Vitamin A groups compared to the paracetamol group. cafeinated paracetamol + Vitamin E however produced a significant increase $(\mathrm{p}<0.05)$ in ALT $(\mathrm{U} / \mathrm{L})$ $(121.44 \pm 1.82)$ compared to the paracetamol group.

There was a significant decrease $(\mathrm{p}<0.05)$ in $\operatorname{ALT}(\mathrm{U} / \mathrm{L})$ in the cafeinated paracetamol +
Vitamin A group $(73.61 \pm 0.80)$ compared to the cafeinated paracetamol group $(89.00 \pm 0.70)$ as well as a significant increase $(\mathrm{p}<0.05)$ in the cafeinated paracetamol + Vitamin $\mathrm{E}$ group compared to the cafeinated paracetamol group. Co-administration of Vitamin $\mathrm{E}$ produced significant decreases $(\mathrm{p}<0.05)$ in AST $(\mathrm{U} / \mathrm{L})$ when administered with paracetamol and cafeinated paracetamol when compared to the cafeinated paracetamol group. Administration of cafeinated paracetamol + Vitamin E also produced a significant increase $(\mathrm{p}<0.05)$ in ALT (U/L) compared to the cafeinated paracetamol + Vitamin A group.

Table 1: Total serum protein and enzymes activities in rats given oral doses of paracetamol or panadol extra with or without vitamin $A$ and $E$.

\begin{tabular}{|c|c|c|c|c|c|}
\hline Group & Treatment & $\begin{array}{c}\text { Total Serum } \\
\text { Protein } \\
(\mathrm{g} / 100 \mathrm{ml})\end{array}$ & AST (U/L) & ALT (U/L) & ALP (U/L) \\
\hline 1 & Control & $5.98 \pm 0.65$ & $17.51 \pm 1.42$ & $73.81 \pm 1.45$ & $76.01 \pm 2.81$ \\
\hline 2 & Paracetamol & $5.93 \pm 0.68^{b}$ & $28.28 \pm 1.96^{\mathrm{a}}$ & $114.34 \pm 0.55^{\mathrm{a}}$ & $121.90 \pm 10.62^{\mathrm{a}}$ \\
\hline 3 & Panadol Extra & $7.53 \pm 1.07 *$ & $23.54 \pm 0.84 *$ & $89.00 \pm 0.70 *$ & $87.97 \pm 2.06^{*}$ \\
\hline 4 & $\begin{array}{c}\text { Paracetamol + } \\
\text { Vitamin A }\end{array}$ & $6.46 \pm 0.86^{\circ}$ & $20.57 \pm 0.70^{*}$ & $92.23 \pm 0.53 *$ & $64.5 \pm 3.40^{*}$ \\
\hline 5 & $\begin{array}{c}\text { Paracetamol + } \\
\text { Vitamin E }\end{array}$ & $8.58 \pm 0.81 *$ & $20.30 \pm 0.72 *$ & $83.35 \pm 0.97 *$ & $68.87 \pm 7.87 *$ \\
\hline 6 & $\begin{array}{l}\text { Panadol Extra } \\
+ \text { Vitamin A }\end{array}$ & $4.66 \pm 0.43^{*}$ & $23.67 \pm 0.96^{*}$ & $73.61 \pm 0.80 *$ & $59.93 \pm 4.89 *$ \\
\hline 7 & $\begin{array}{c}\text { Panadol Extra } \\
+ \text { Vitamin E }\end{array}$ & $6.29 \pm 1.05^{\circ}$ & $18.83 \pm 0.59 *$ & $121.44 \pm 1.82^{*}$ & $84.75 \pm 4.27 *$ \\
\hline
\end{tabular}

Values presented as mean $\pm \mathrm{SD} ; \mathrm{n}=6$; $* \mathrm{p}<0.05$ compared to the paracetamol group, ${ }^{*} \mathrm{p}<0.05$ compared to the paracetamol group, ${ }^{\mathrm{a}} \mathrm{p}<0.05$ compared to the control, ${ }^{\mathrm{b}} \mathrm{p}>0.05$ compared to control. Dose of paracetamol = $171.43 \mathrm{mg} / \mathrm{kg}$, Dose of paracetamol in cafeinated paracetamol $=171.43 \mathrm{mg} / \mathrm{kg}$, Dose of caffeine in cafeinated paracetamol $=10.286 \mathrm{mg} / \mathrm{kg}$, Dose of Vitamin A $=4.286 \mathrm{mg} / \mathrm{kg}$, Dose of Vitamin E $=1428.57 \mathrm{iu} / \mathrm{kg}$.

\section{Discussion}

Paracetamol administration produced a decrease in total serum protein while caffeinated paracetamol as well as supplementation with antioxidant vitamins $\mathrm{A}$ and $\mathrm{E}$ caused increases in total serum protein above that of the control group. However, the co-administration of vitamin A and paracetamol extra resulted in a decrease in total protein.

The commonest enzymes employed as indicators of hepatocellular damage are the transaminase enzymes (Aspartate aminotransferase; AST and Alanine aminotransferase; ALT) and Alkaline phosphatase; ALP. Damage to the liver results in increase in their activities in plasma. Increases in serum enzyme activities are roughly proportional to the extent of tissue damage (Gaw et al, 1995). Serum enzyme activities such as AST, ALT and ALP were increased following paracetamol administration. Similarly, the caffeination of paracetamol resulted in a reduction in the level of these enzymes. Further reductions were observed following the administration of vitamins $\mathrm{A}$ and $\mathrm{E}$; however the administration of vitamin $\mathrm{E}$ alongside with caffeinated paracetamol resulted in increased levels of ALP and ALT.

Increase in liver enzymes in serum following paracetamol administration has earlier been reported (Gaw et al, 1995 and Hardman et al, 1996). It has also been reported that paracetamol could be bioactivated enzymatically by cytochrome $\mathrm{P}_{450} 2 \mathrm{EI}$ in both the liver and the kidney (Hu et al, 1993). Metabolic activation by cytochrome $\mathrm{P}_{450}$ and prostaglandin synthase are known to catalyse the conversion of paracetamol to the reactive 
intermediate, $\mathrm{N}$-acetyl parabenzoquinoneimine (NAPQI) which is believed to play an important role in paracetamol mediated toxicity (Raucy et al, 1989). Proinflammatory cytokines such as tumor necrosis factor alpha (TNF- $\alpha$ ) and interleukin- $1 \alpha$, that are released in response $t$ paracetamol intoxication are thought to be responsible for some pathlogical manifestations of paracetamol-induced hepatotoxicity (Blazka et al, 1995).

The cumulative oxidative damage is likely one of the mechanisms producing the hepatotoxic effects of paracetamol administration in this study. The observed higher increase in the level of ALT over AST may be due to a leakage of cytoplasmic enzymes into circulation as a result of inflammation of the liver cells. The molecular mechanism by which the antioxidant vitamins, and caffeine reduce liver damage maybe due to their ability to maintain liver cell integrity even in the presence of a hepatotoxic agent such as paracetamol.

\section{Conclusion}

This study reveals that vitamins $\mathrm{A}$ and $\mathrm{E}$ as will as caffeine have protective roles in the maintenance of liver cell integrity even in the presence of a hepatotoxic agent such as paracetamol.

\section{References}

Donninger, L. P., Hulson, D. H. and Pickering, B. A. (1972). Modified Biuret Method of Protein estimation. Biochem. J., 216: 701 707.

Gaby, S. K., Bendich, A., Singh, V. N., Machlin, L. D. (1991). In: Vitamin Intake and Health: A scientific Review, Marcel Dekker Inc. New York.

Hardman, J. G., Limbird, L. D., Goodman and Gilman, (1996). The Pharmacological Basis of Therapeutics. McGraw Hill company, NY: 617 - 682, 1573 - 1590.

Keaton, M. R. (1988). Acute Renal failure in Alcoholics During Therapeutic

Acetaminophen ingestion, South Med. J. 81: 1163 - 1166.

Laurence, D. R., Benneh, P. N., Brown, M. J. (1997). Clinical pharmacology. Churchill Livingstone, NY: $249-688$.

Mathieu, M., Guidolet, J., Junien, C. I., Lalegerie, P. (1982). Commission Enzymologic: Recommendations for determining the catalytic concentration of Alanine Aminotransferase in human serum at $30^{\circ} \mathrm{C}$, Ann Biol. Clin 40: $132-138$.

Raucy, J. L., Lasker, J. M., Lieber, C. S. and Black, M. (1989). APAP Activation by human liver cytochromes $\mathrm{P}_{450} 2 \mathrm{EI}$ and $\mathrm{P}_{450}$ IA2. Arch. Biochem. Biophys. 271: $270-$ 283.

Siedel, J., Rollingger, N., Rosekan, P. and Ziegenhorn, J. (1985). Cholesterol, methods of enzymatic analysis. $3^{\text {rd }}$ ed. 3 : $19-28$.

Steiner, M., Glantz, M. and Lekos, A. (1995). Vitamin E plus Aspirin Compared to Aspirin alone in patients with transient ischemic attacks, Am. J. Clin. Nutr. 62: 13815 - 13845 .

Udosen, E. O., Mbissah, J. A. and Akpanabiatu, M. I. (1998). Plasma lipoprotein cholesterol levels in normal and protein energy malnourished children in Nigeria, Mary Slessor J. Med. 12: $51-54$. 